have been opened up; and a stone age trench now being examined is found to be covered with a wellmarked line of turf underlying the later prehistoric rampart. It contains large masses of material of the stone and early bronze ages, while on top of the trench numerous sherds of elaborately decorated Early Bronze Age pottery are being identified.

Excavations have also been resumed on behalf of the Ipswich Museum under the direction of the curator, Mr. Guy Maynard, on the Stanton Chair Farm Roman site between Ixworth and Stanton in Suffolk, where investigations were initiated last autumn as a result of the observation of Roman potsherds and tile fragments in a field. Although it is known that the area of the site is at least two hundred feet across, operations at present are confined to a narrow strip, as the ground is under crops. Work, accordingly, has been concentrated on clearing the remains of a bath-house, of which the hypocaust pillars are well preserved, and a drain from the cement floor of an adjacent room still remains. Two levels of flooring and coins of Marcus Aurelius (A.D. 161-186) and Eugenius (A.D. 393) suggest a prolonged, but interrupted occupation. Six weeks of excavation at Castle Dore, an Iron Age hill-fort, near Fowey, in Cornwall, under the direction of Mr. Ralegh Radford, with the unemployed for labour, has confirmed previous conclusions as to its character. It was evidently a strong point commanding the ancient prehistoric road and trade route across the peninsula. It is now considered beyond reasonable doubt that this was, as has been suggested, the palace of the King Mark of Arthurian legend. Students of the University of Liverpool excavating, also with the assistance of local unemployed, on Eddisbury Hill, Cheshire, have brought to light traces of an ancient fortress in the form of walls of local sandstone, five to six feet in height, in an excellent state of preservation.

\section{Ultra-short Wave Radio Communication}

THE practical application of ultra-short waves to radio communication made a step forward on June 11, when R.C.A. Communications Inc. gave a public demonstration of their new circuit connecting New York with Philadelphia. A brief illustrated description of this demonstration is given in the June issue of Communication and Broadcast Engineering (U.S.A.). The circuit operates over a distance of about 91 miles with the aid of two automatic relay stations situated between the terminal stations at New York and Philadelphia, the longest individual link being 36 miles. A two-way service is provided, and the six wave-lengths required are in the neighbourhood of three metres; the stations are equipped for the transmission of drawings, typescript and other visual material in facsimile, with simultaneous operation of typewriter and telegraph channels. The article referred to above includes a schematic diagram of the circuit which is reproduced from one actually transmitted to New York by the facsimile circuit. The transmitters make use of resonant line circuits in order to secure frequency stability, while the receivers incorporate the new acorn tubes specially produced for ultra-short wave purposes.

AN interesting feature of the new installation is the method by which the unattended relay stations may be turned on or off from either of the terminal stations. The receivers at each of the four stations are always alive and available for reception from their corresponding transmitters. When it is desired to make the circuit ready for traffic, New York or Philadelphia sends out a tone modulation on its carrier wave. This tone is accepted by the receiver at the first relay station, and is caused to start up its own transmitter, which then passes the tone modulation on to the second relay station. The operation is repeated here and also at the other terminal station, where the tone is re-transmitted back through the relay stations on the return circuit. Thus when the tone signal is received back at the terminal station from which it originated, it is known that all six transmitters are in operation and the radio circuit is ready to pass traffic. When the circuit is no longer required, the tone is removed and the transmitters are automatically switched off, one by one, in the same sequence.

\section{League of Nations Reform}

IN a pamphlet entitled "Anarchy or Peace", Lord Davies discusses the dangers of the present situation in Europe and the possibilities of avoiding the outbreak of an even more disastrous European war (London: The New Commonwealth. 9d.). Referring to the defects of the League of Nations as demonstrated by recent events, Lord Davies asserts that these were due to the absence of an equity tribunal and international police force, and more particularly to the lack of cohesion and determination on the part of States members of the League. Accordingly, he heavily discounts a good many of the proposals to reform the League as designed rather to deprive the League of the very functions which would enable it to secure the peace of the world if its machinery were honestly and whole-heartedly used. Proposals to substitute a series of regional pacts are only too certain to plunge us back in the pre-War system with its inevitable outcome. Lord Davies argues that the only solution of our present dangerous situation lies first in the creation of peaceful procedure for the settlement of all disputes and the revision of treaties. For this purpose, in default of a more satisfactory solution, an equity tribunal holds the field. Secondly, an international police force is required, and he urges once more the equipment of a European air police force under the control and direction of a neutral authority, a reconstituted League. This force must be superior in numbers and equipment to the national air force of any European State which refuses to join in the guarantee. Only a scheme on these lines will suffice to restore the confidence of the smaller powers in the integrity and good faith of the great powers, and endow the League with the superiority of force essential for the establishment of the rule of law. 